\title{
How to Manage the Unmanageable Classes?
}

\author{
Senem Üstün Kaya* \\ Assistant Professor, Başkent University - English Language Teaching Department, Ankara-Turkey
}

\begin{abstract}
Developing effective classroom management in 21st century classrooms is a challenging task for all teachers including experienced, novice, young and old. Although many researches have been conducted to present effective classroom strategies, no single technique, admittedly, can be accepted as the most appropriate for teachers and situations. Whether the applied strategies work in the classrooms has become another research area for educators (Altınel, 2006; Baker \& Westrup, 2000; Demir, 2009; Tahir \& Qadir, 2012). Researchers have conducted studies on CM problems and students' perception of teachers' management skills (Aydin \& Bahçe, 2001; İnceçay \& Dollar, 2012; LaMaster, 2001; Merç, 2004,). Almost in all studies, classroom management is considered to be the actions taken by the teacher to set order and discipline during lessons (Doyle, 1986). These actions can be listed as asserting the authority, developing a management plan to make learning efficient, setting discipline and order for safe learning environment, leading students to take responsibilities for their own learning and applying methods to solve problems and conflicts in class. This study aims at clarifying the term Classroom Management (CM); presenting drawbacks in classroom management and involving efficient classroom management strategies and suggestions for the teachers.
\end{abstract}

Keywords: classroom management, strategies, discipline, drawbacks in CM

\section{WHAT IS CLASSROOM MANAGEMENT?}

What is Classroom Management in general? The term CM, most commonly used as 'classroom control' and 'classroom discipline', is often used to refer to behavior modification and discipline set for the sake of students in learning process. Feiman-Neimser (2001) defined effective classroom management as 'arranging the physical and social conditions so that learners have growth-producing experiences' (p. 17). The main goal of classroom management is to establish guidelines for the appropriate behaviors in order to provide a 'positive climate' (Tuncay, 2010) where students learn efficiently by participating in the activities willingly and interacting with each other in a peaceful environment. Such positive classes can be achieved by teachers who modify behaviors by setting rules in order to enhance students' academic success.

As Kayıkçı (2009) stated a dull, noisy and disorganized classroom environment has negative impacts on students' learning and increases classroom management problems. There are certain factors that influence creates drawbacks in classroom management: a disorganized learning environment, personal factors, family problems, physical, social and emotional changes (particularly in adolescence), sociocultural differences, lack of motivation and low level of interaction with the teacher (Matus, 1999). For McPhillimy (1996), negative issues which influence the maintenance of CM can be related to too much noise, students' asking for the toilet, denial to obey the rules, disorganized classroom setting, swearing and bullying peers in class and persistence to act accordingly in class. On the other hand, classes where students feel safe and confident are highly bound to teacher's attitudes and abilities in classroom management.

Within this frame, it is exceedingly necessary to discuss 'teacher efficacy' as an important issue in education because ineffective teachers are often reported as having difficulties with coping disruptive classroom behaviors. Guskey \& Passaro (1994) defined teacher efficacy as 'teachers' belief or conviction that they can influence how well students learn, even those who may be difficult or demotivated' (p. 4). Teacher's efficacy depends highly not only on their academic and pedagogical background but also on their classroom management skills and experiences. When teachers lack the abilities to handle problems in class, the results will be low student achievement, lack of students' motivation and interest in learning. It is an undeniable fact that teachers' sense of efficacy gains a crucial role in schooling because strong efficacy leads to effort and performance, which increases students' performance and academic success (Tschannen-Moran, Woolfolk Hoy and Hoy, 1998).

For Kyriacou (1997), the essence of effective teacher lies in applying certain methods to foster students' learning. Within this context, Kyriacou offered some components as effective teaching skills:

- Planning and preparation: determining the teaching goals and outcomes for a lesson and using methods to achieve aims

- Lesson presentation: skills to involve all the students in learning process

- Lesson management: skills of selecting the proper activities and implementing them in teaching 
- Classroom climate: maintain a positive atmosphere for the students

- Discipline: setting a good order and solving problems in class

- Assessing pupils' progress: skills that involve the assessment of students' progress

- Reflection and evaluation: skills of evaluating each student individually and giving feedback for further development (p. 8).

Classroom management is an important aspect of teacher effectiveness. For Emmer \& Stough (2001), to maintain order in the classroom, two features have been identified: identifying the desirable behaviors and preventing the undesirable ones. Desirable rules can be identified via rule setting and clarifying the reasons of regulations and undesirable rules can be prevented when teachers consider the essential misbehaviors that can violate the class harmony and unity.

There are certain strategies for teachers to maintain a coherent learning environment for students. Students need to know their limits in accordance with the set of classroom rules and regulations. The use of rules is a preventive component of classroom management because they reinforce the desired behaviors and prevent the undesired ones. Classroom rules need to be determined and clarified by the teacher at the beginning of each course period. In a pre-structured and well-organized learning environment, teacher sets behavioral rules, monitors the students, and rewards the good behaviors while reacting to the inappropriate ones. It would be proper to remember that when rules are stated positively rather than worded with 'not' (Kerr \& Nelson, 2002) in a simple sentence, students easily remember them and feel more motivated to obey. Within the period, students should be aware of the fact that they must bear the consequences of their behaviors if they violate the rules. Although some educators state that students obey the rules due to fear which might create boredom and lack of interest in learning, many teachers believe in the significance of teachers as the external regulators. Obeying the rules in class can also increase learners' intrinsic motivation. It should be kept in mind that it is not important to set rules, rather making students realize the significance and reason of rules and obeying them to contribute to their learning process is important. Not only individual teachers but also schools should establish schoolwide rules.

Another strategy for effective classroom management is 'consistency'. It is accepted as the centerpiece of effective classroom management fair and firm discipline should be the target for a peaceful and unified atmosphere in class. By achieving both, teachers can easily provide students peaceful learning environments in which students perform the tasks and engage in learning efficiently (Brophy, 1999a). In this sense, routines incorporated by the teacher enable teachers to organize the learning environment, time and effective management. Certain behavior strategies as rewarding or punishing every student with a fair attitude should also be included in routines and rules of class to preserve constituent flow of the lessons.

Classroom Management is not merely bound to setting a class discipline for a positive learning environment. Rather, choices of tasks, course books and materials also create a more meaningful and efficient learning environment. When students consider the teaching materials effective and relevant, they tend to participate in the activities more and avoid disrupting behaviors. When lessons are well-planned and teachers use time efficiently, students feel more motivated and enthusiastic. Guided practice and feedback of teachers also provide more effective lessons. As Sutherland \& Wehby (2001) stated, when students are provided with opportunities to actively engage in activities, they become less disruptive and gain a consistent academic success.

Classroom structuring also provides a positive atmosphere in terms of control and guidance for teachers. One of the most important components of classroom management is to create a safe learning environment. Making seating arrangements will maximize behavior management and will not only decrease the inappropriate behavior but also will increase students' participation, interaction and motivation. A wellorganized setting will help teachers to interact with the students, respond to their questions, monitor the behaviors of learners and provide immediate feedback.

Baker and Westrup (2000) put forward certain strategies as balancing TTT (Teacher Talk Time) and STT (Student Talk Time); giving clear instructions for the activities; using language consistently and preparing lessons according to students' learning abilities. For Kayıçı (2009), setting a positive teacher-student communication, caring students' needs and interests; motivating students; setting reasonable classroom rules and organizing the settings of students are the key factors for an appropriate classroom discipline.

For effective classroom management, teacher training programs may provide teachers skills in terms of class control and efficacy. For Ashton (1984), a teacher training program should be designed and implemented in such a way for the trainees to develop their practical skills, human relationship abilities and teaching efficacy. 


\section{CONCLUSION}

It is a well-known fact that for effective teaching, CM is the basis which creates essential impetus for the learner in teaching process. An effective classroom management maximizes students' learning opportunities while contributing to their academic achievement (Brophy, 1999b; Wang, Haertel \& Walberg, 1993). Classroom management strategies are beneficial to the cognitive development of students and motivating in learning process (McCaslin \& Good, 1992).

For positive educational outcomes, classroom management is closely related to teacher's personality and his/her interaction with the students. Developing empathy and caring students' needs and interests might also help teachers to create a safe and enjoyable learning environment for the students. Teacher preparation and training programs, clarifying the class rules and routines, consistency, handling relationships and solving problems immediately, choosing appropriate tasks and in-class materials and a constructive communication of teachers provide positive classroom contexts while increasing students' motivation and self-discipline. If implemented in a controlling way, these classroom management strategies underscore the significance of positive behaviors, which also promote students' intrinsic motivation. It should also be noted that when students gain self-regulation and discipline, they gain academic success and permanent learning.

\section{REFERENCES}

[1]. Ashton, P. T. (1984). Teaching efficacy. Journal of Teacher Education, 25 (2), 41-54.

[2]. Baker, J. \& Westrup, H. (2000). The English language teacher's handbook. London: Continuum.

[3]. Brophy, J. (1999a). Perspectives of classroom management. In J. H. Freiberg (Ed.), Beyond behaviorism: Changing the classroom management paradigm (pp. 43-56). Boston: MA: Alyn \& Bacon.

[4]. Doyle, W. (1986). Classroom organization and management. In M.C. Wittrock (Ed.), Handbook of research on teaching. A project of the American Educational Research Association (pp. 392-431). New York: Macmillan.

[5]. Emmer, E. T. \& Stough, L. M. (2001). Classroom management: A critical part of educational psychology, with implications for teacher education. Educational Psychologist, 36(2), 103-112.

[6]. Feiman-Nemser, S. (2001). Helping novices learn to teach: Lessons from an exemplary support teacher. Journal of Teacher Education, 52(1), 17-30.

[7]. Guskey, T. \& Passaro, P. (1994). Teacher efficacy: A study of construct dimensions.

[8]. American Educational Research Journal, 31, 627-643.

[9]. Kayıkçı, K. (2009). The effect of classroom management skills of elementary school teachers on undesirable discipline behavior of students. Procedia Social and Behavioral Sciences 1, 1215-1225.

[10]. Kerr, M. M. \& Nelson, C. M. (2002). Strategies for addressing behavior problems in the classroom (5 $5^{\text {th }}$ ed.). Colombus, $\mathrm{OH}$ : Merrill Prentice Hall.

[11]. Kyriacou, C. (1997). Effective Teaching in Schools Theory and Practice ( $2^{\text {nd }}$ ed.). UK: Stanley Thornes Ltd.

[12]. Matus, D. E. (1999). Humanism and effective urban secondary classroom management. The Clearing House, May/June, 305-307.

[13]. McCaslin, M. \& Good, T. L. (1992). Compliant cognition: the misalliance of management and instructional goals in current school reform. Educational Researcher, 21(3), 4-17.

[14]. McPhillimy, B. (1996). Controlling your class. West Sussex: John Wiley \& Sons Ltd.

[15]. Sutherland, K. S. \& Wehby, J. H. (2001). Exploring the relationship between increased opportunities to respond to academic requests and the academic and behavioral outcomes of students with EBD. Remedial and Special Education, 22(2), 113-121.

[16]. Tschannen-Moran, M., Woolfolk Hoy, A. \& Hoy, W. K. (1998). Teacher efficacy, its meaning and measure. Review of Educational Research, 2, 202-248.

[17]. Tuncay, H. (2010). Class management in ELT: Who is the boss? Retrieved from http://hidayettuncay.com/makaleler/CLASS-MANAGEMENT-NT-IN-ELT. pdf

[18]. Wang, M. C., Haertel, G. D. \& Walberg, H. J. (1993). Toward a knowledge base for school learning. Review of Educational Research 63(3), 249-294. 